\title{
USULAN REKOMENDASI OPTIMALISASI PENCEGAHAN DAN PENGENDALIAN PENYAKIT COVID-19 DI MASYARAKAT (Studi Di Wilayah Kerja Dinas Kesehatan Provinsi Jawa Timur)
}

\author{
Satriya Wijaya*, Akas Yekti Pulih Asih, Maya Purnia Sari, Aliya Zahro Fuadah \\ Fakultas Kesehatan (Program Studi S1 Kesehatan Masyarakat), Universitas Nahdlatul Ulama Surabaya, \\ Kota Surabaya, Indonesia \\ email: swijaya7@unusa.ac.id
}

\begin{abstract}
Abstrak
Coronavirus Disease 2019 (Covid-19) merupakan penyakit jenis baru yang belum teridentifikasi sebelumnya. Penyebab masih tingginya angka kasus positif covid-19 di dalam negeri karena penularan yang masih aktif. Penelitian ini bertujuan untuk memberikan usulan rekomendasi optimalisasi pencegahan dan pengendalian penyakit Covid-19 di masyarakat pada wilayah kerja Dinas Kesehatan Provinsi Jawa Timur. Penelitian ini bersifat kualitatif induktif dengan metode deskriptif. Sampel pada penelitian ini adalah semua petugas pencegahan dan pengendalian penyakit Covid-19 terkait serta stakeholder Dinas Kesehatan Provinsi Jawa Timur. Data didapatkan melalui teknik pengumpulan data observasi, wawancara dan studi dokumen. Hasil analisis data menunjukkan Rencana Operasional Strategi Komunikasi Pesan Kunci Covid-19 Dinkes Tingkat Provinsi Jawa Timur sudah baik, perlu dilakukan secara berkelanjutan, persiapan dalam mengakomodir rencana atau langkah-langkah ke depan dalam upaya optimalisasi pencegahan dan Pengendalian Penyakit Covid-19. Saran untuk Dinkes Provinsi Jawa Timur perlu menambahkan materi sosialisasi terkait urgensi dan pentingnya pelaksanaan PPKM, mengadakan perekrutan tenaga kesehatan, penambahan tenaga kesehatan yang ditempatkan di rumah sakit lapangan dan melaksanakan kegiatan media promosi kesehatan.
\end{abstract}

Kata kunci: optimalisasi, pencegahan, pengendalian, covid-19

\begin{abstract}
Coronavirus Disease 2019 (Covid-19) is a new type of disease that has not been previously identified. The reason for the high number of positive cases of Covid-19 in the country is because the transmission is still active. This study aims to provide recommendations for optimizing the prevention and control of Covid-19 disease in the community in the working area of the East Java Provincial Health Office. This research is inductive qualitative with descriptive method. The sample in this study were all related Covid-19 disease prevention and control officers and stakeholders from the East Java Provincial Health Office. Data obtained through data collection techniques Observation, interviews and document studies. The results of data analysis show that the Operational Plan for the Covid-19 Key Message Communication Strategy of the East Java Provincial Health Office is good, it needs to be carried out continuously, preparations to accommodate plans or future steps in an effort to optimize the prevention and control of Covid-19. Suggestions for the East Java Provincial Health Office need to add socialization materials related to the urgency and importance of implementing PPKM, recruiting health workers, adding health workers placed in field hospitals and carrying out health promotion media activities.
\end{abstract}

Keywords : optimization, prevention, control, covid-19

\section{PENDAHULUAN}

Coronavirus Disease 2019 (Covid-19) merupakan penyakit jenis baru yang belum teridentifikasi sebelumnya dan saat ini telah menyerang manusia. Virus tersebut muncul pertama kali di Kota Wuhan, Provinsi
Hubei, Cina dan sudah ada sejak akhir tahun 2019 yang lalu. Diameter virus Corona diperkirakan mencapai 125 nanometer atau sama dengan 0,125 mikrometer (Purwanto, 2020). Meskipun sangat kecil dan tidak dapat terjangkau oleh kasat mata manusia, 
virus tersebut sangatlah berbahaya karena mampu bertahan 10 menit di permukaan, termasuk di tangan. Bahkan World Health Organization (WHO) menyebut bahwa virus Corona dapat bertahan beberapa jam hingga beberapa hari dan dapat bertahan hidup pada suhu 26-27 derajat celsius.

Pada awal penyebaran Covid-19 di Wuhan, banyak berita bermunculan sehingga beberapa negara pun mulai panik, namun ada juga negara yang santai ketika mendengar virus tersebut sudah mulai ada hingga menyebar ke seluruh dunia. Virus semacam itu bukanlah pertama kali ada dalam sejarah manusia, karena dulu ada beberapa virus yang telah mengancam manusia di seluruh dunia, salah satunya yaitu Flu Burung. Virus tersebut menjadi isu yang paling menghebohkan di dunia, termasuk di Indonesia. Banyak negara memilih upaya pencegahan ekstrem seperti Lockdown karena cepatnya penyebaran serta mudahnya penularan Covid-19. Tentunya jika negara Indonesia menerapkan kebijakan lockdown maka akan timbul dampak positif dan negatif dari wabah virus Corona ini. Dampak positif dari adanya penerapan kebijakan tersebut tentunya akan meminimalisir penyebaran.

Menurut Sekretaris Pengurus Pusat Perhimpunan Dokter Umum Indonesia (PDUI) Dr. Ardiansyah Bahar penyebab masih tingginya angka kasus positif Covid19 di dalam negeri karena penularan yang masih aktif terjadi di masyarakat. "Hal ini bisa terjadi karena anjuran untuk menjalankan protokol kesehatan belum sepenuhnya dijalankan dengan baik. Diinformasikan bahwa per 7 Februari 2021 jumlah kasus kumulatif terinfeksi virus Covid-19 di Indonesia mencapai 1.147.010 kasus dengan jumlah kasus meninggal sebanyak 31393 orang. Provinsi Jawa Timur menduduki peringkat ke-2 tertinggi setelah Provinsi DKI Jakarta. Kasus kumulatif Covid-19 di Jawa Timur sebesar 117.294 kasus dengan jumlah kasus meninggal 8.114 kasus.

Di tingkat Provinsi, Dinas Kesehatan Provinsi merupakan role model yang menjadi panutan sekaligus koordinator utama yang mempunyai peran sangat penting untuk mendukung Dinas Kesehatan di tingkat Kabupaten/Kota dalam menanggulangi dan melakukan pencegahan penyakit menular salah satunya penyakit Covid-19 ini. Oleh karena itu, melihat jumlah kasus kumulatif penyakit Covid-19 di wilayah Provinsi Jatim, maka idealnya Dinas Kesehatan Provinsi Jawa Timur perlu melakukan upaya konkrit dalam mengoptimalkan kegiatan pencegahan dan pengendalian penyakit Covid-19 pada masyarakat di wilayah Provinsi Jawa Timur.

Tujuan penelitian ini adalah menyusun suatu rekomendasi yang bisa dijadikan pedoman praktis yang dapat dijadikan acuan untuk Optimalisasi Pencegahan dan Pengendalian Penyakit Covid-19 pada masyarakat di wilayah kerja Provinsi Jawa Timur.

\section{METODE PENELITIAN}

Jenis penelitian ini bersifat kualitatif induktif dengan metode deskriptif. Penelitian ini dilakukan mulai bulan April 2021 sampai bulan November 2021. Dalam mengumpulkan data yang dibutuhkan, peneliti menggunakan teknik pengumpulan data observasi, wawancara dan studi dokumen. Instrumen penelitian menggunakan lembar pertanyaan wawancara. Kegiatan observasi dan wawancara dilakukan untuk mengetahui kegiatan dan kejadian tentang sejauh mana kegiatan pencegahan dan pengendalian penyakit Covid-19 pada masyarakat di wilayah kerja Dinas Kesehatan Provinsi Jawa Timur. Sampel pada penelitian ini menggunakan sampel jenuh, sehingga sampel pada penelitian ini adalah semua petugas dan stakeholder unit terkait yang bertugas mengakomodir dan melaksanakan kegiatan pencegahan dan pengendalian penyakit Covid19 pada masyarakat di wilayah kerja Dinas Kesehatan Provinsi Jawa Timur.

\section{HASIL DAN PEMBAHASAN}

Kebijakan Dinas Kesehatan Provinsi Jawa Timur Yang Mendukung Optimalisasi Pencegahan dan Pengendalian Penyakit Covid-19

Kebijakan Dinas Kesehatan Provinsi Jawa Timur untuk optimalisasi pencegahan dan pengendalian penyakit Covid-19 merujuk pada beberapa kebijakan yaitu Kepmenkes RI No. 413 tahun 2020 tentang Pedoman 
Pencegahan Pengendalian Covid-19 secara menyeluruh, Kepmenkes RI No. 4794 tahun 2021 terkait Penggunaan Rapid Antigen Berdasar Kriteria Kabupaten/Kota yang diterapkan oleh kabupaten/kota, Kepmenkes RI No. 4641 tahun 2021 tentang Panduan Pelaksanaan Pemeriksaan, Pelacakan Karantina dan Isolasi Dalam Rangka Percepatan Pencegahan dan Pengendalian Covid-19, Instruksi Menteri Dalam Negeri (InMendagri) Nomor 35 tahun 2021 yang berisi peraturan tentang Pemberlakuan Pembatasan Kegiatan Masyarakat Level 4, Level 3, dan Level 2 Covid-19 di wilayah Jawa dan Bali, kepmenkes RI No. 4805 tahun 2021, Inmendagri No. 27 tahun 2021 terkait 6 indikator untuk menilai PPKM, Kepmenkes RI No. 4642 tahun 2021 tentang Penyelenggaraan Laboratorium Pemeriksaan Corona Virus Disease 2019 (Covid- 19), Permenkes RI No. 12 tahun 2021 tentang Juknis Penggunaan Dana Alokasi Khusus Non Fisik Bidang Kesehatan Tahun Anggaran 2021 yang berisi terkait anggaran untuk mengakomodir kegiatan tracer yang dilakukan dari unsur nakes, unsur TNI/Polri, unsur kader atau karang taruna dan Buku Pedoman Pencegahan dan Pengendalian Covid-19 Kemenkes RI tahun 2020.

Beberapa kebijakan dan buku pedoman tersebut, Dinas Kesehatan Provinsi Jawa Timur telah melakukan sosialisasi ke masyarakat dalam bentuk 3 materi yaitu anjuran untuk melakukan test swab antigen, pentingnya melakukan protokol kesehata (prokes) secara ideal, edukasi tentang $5 \mathrm{M}$ (Mencuci tangan, Memakai masker, Menjaga jarak, Menjauhi kerumunan, mengurangi mobilitas) yang di share ke media-media sosial seperti whatsapp, instagram, facebook dan media sosial lainnya.

Kecukupan SDM Yang Bertugas Dalam Pencegahan dan Pengendalian Penyakit Covid-19 dan Kecukupan Anggaran/Dana Yang Dimiliki Dinas Kesehatan Provinsi Untuk Mendukung Terwujudnya Optimalisasi Pencegahan dan Pengendalian Penyakit Covid-19

Jumlah sumber daya manusia yang bertugas dalam pencegahan dan pengendalian penyakit Covid-19 pada setiap Rumah Sakit menurut tempat tidur sekiranya sudah cukup (1 tempat tidur $=1$ orang perawat, 1 orang dokter). Ketika ada lonjakan kasus, maka menambah kapasitas tempat tidur sehingga mengakibatkan kekurangan tenaga nakes karena tidak memungkinkan memforsir tenaga nakes karena ada aturan jam kerja. Sedangkan untuk RS lapangan yang diperuntukkan isolasi Covid-19 gejala ringan masih banyak yang kekurangan nakes.

Untuk sumber daya manusia di fasilitas kesehatan primer yang bertugas dalam pencegahan dan pengendalian penyakit Covid-19 dapat dikatakan sudah cukup, kecuali untuk petugas TLI (test lacak isolasi) masih mengalami kekurangan petugas, untuk petugas tracer sejawa timur yang masuk di pembiayaan BOK saat ini berjumlah 11623 orang tracer. Idealnya menurut kebijakan Kemenkes RI No. 4641 tahun 2021 tentang panduan pelaksanaan pemeriksaan, pelacakan karantina dan isolasi dalam rangka percepatan pencegahan dan pengendalian Covid-19 menganjurkan bahwa petugas TLI (test lacak isolasi) di setiap Puskesmas harus mempunyai minimal 2 orang petugas TLI (test lacak isolasi).

\section{Fasilitas Kesehatan yang Dimiliki di Wilayah Kerja Dinas Kesehatan Provinsi Jawa Timur}

Berdasar hasil wawancara mendalam dengan para stakeholder Dinas Kesehatan Provinsi Jawa Timur dari semua fasilitas kesehatan yang ada di wilayah Provinsi Jawa Timur, kondisi fasilitas kesehatan seluruhnya dalam kondisi baik dan layak operasional. Untuk kelengkapan alat maupun sarana prasarana kondisinya cukup lengkap dan untuk ketersediaan alat kesehatan seperti: alkohol swab, spuit, Covid-Safety box, APD vaksinasi, masker N95, masker KN95, masker bedah, hazmat, safety google, RDT IgG/IgM Covid-19, RDT Covid-19 Ag Test, RNA Kit, PCR Kit, PCR Tube, RTPCR VTM, Bio VTM, Swab dacron, HandSchoen, Face Shield, Kapas, Sepatu Boot, Hair Net, Hand Sanitizer, Shoes Cover, Apron, Oksimeter, Sample Collection Kit Module 8 CoolBox dalam menanggulangi Covid-19 di masyarakat selalu mendapatkan support dropping alat kesehatan dari Kementerian Kesehatan dan pengadaan dari Dinas Kesehatan Provinsi Jawa Timur untuk didistribusikan melalui 
Dinas Kesehatan kabupaten/kota. Sehingga perlu penambahan sarana prasarana fasilitas kesehatan seperti tempat tidur (bed patient) dan sarana prasarana lain yang bermanfaat untuk pelayanan pasien Covid-19.

Tabel 1. Rekapitulasi Fasilitas Kesehatan Primer di Wilayah Dinas Kesehatan Provinsi Jatim

\begin{tabular}{lc}
\hline \multicolumn{1}{c}{ Jenis Fasilitas Kesehatan } & Jumlah Fasilitas Kesehatan \\
\hline Puskesmas Rawat Jalan & 402 \\
Puskesmas Rawat Inap & 566 \\
Ponkesdes & 3213 \\
Klinik Pratama Rawat Inap & 596 \\
Klinik Pratama Rawat Jalan & 930 \\
Klinik Utama Rawat Inap & 159 \\
Klinik Utama Rawat Jalan & 72 \\
\hline
\end{tabular}

Sedangkan untuk jumlah laboratorium jejaring pemeriksa COVID-19 untuk pemeriksaan RT-PCR di Jawa Timur sampai dengan 31 Desember 2020 adalah sebanyak 86 laboratorium yang tersebar di 32 kabupaten/kota, sedangkan laboratorium yang dapat melakukan pemeriksaan TCM ada sebanyak 38 laboratorium yang tersebar di 29 kabupaten/kota. Untuk jumlah Laboratorium pemeriksa disajikan pada Gambar 1.

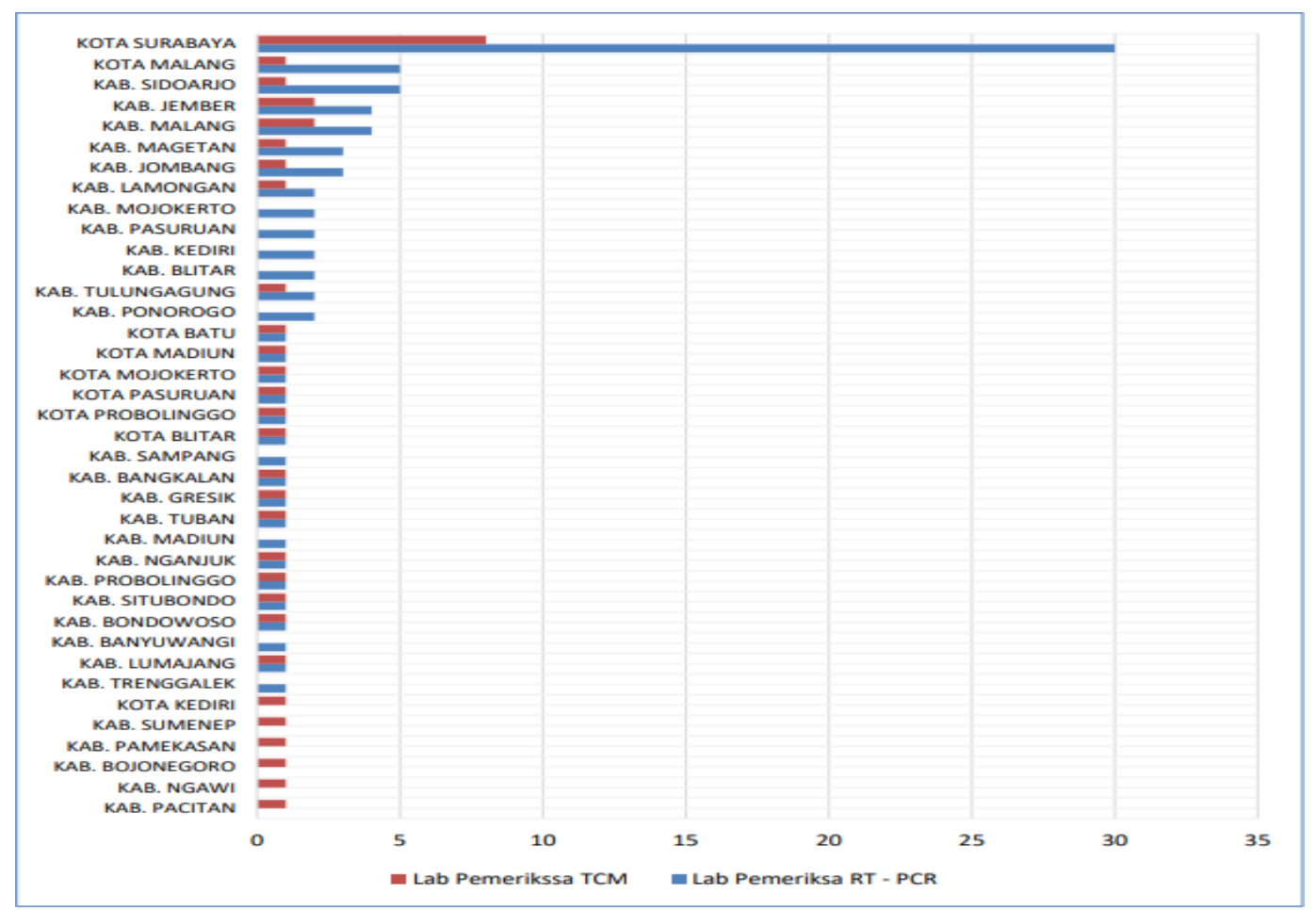

Sumber: Seksi Surveilans dan Imunisasi Dinas Kesehatan Provinsi Jawa Timur

Gambar 1. Jumlah Laborat Pemeriksa Covid-19 di Provinsi Jatim tahun 2020

Berdasarkan gambar 1 diinformasikan bahwa jumlah Laborat pemeriksa Covid-19 (Lab.
Pemeriksa TCM dan Lab Pemeriksa RT-PCR) terbanyak ada di wilayah Kota Surabaya. 
Tingkat Pengetahuan Masyarakat Jawa Timur Tentang Cara Pencegahan dan Pengendalian Penyakit Covid-19

Tabel 2. Persepsi/Pengetahuan Masyarakat tentang Responden Kesehatan terhadap Pencegahan Covid-19 di Wilayah Kerja Dinas Kesehatan Provinsi Jawa Timur

\begin{tabular}{llc}
\hline No & \multicolumn{1}{c}{ Protokol Kesehatan } & $\begin{array}{c}\text { Jumlah } \\
\text { Persepsi } \\
\text { (dalam \%) }\end{array}$ \\
\hline 1. & $\begin{array}{l}\text { Memakai masker } \\
\text { 2. }\end{array}$ & $\begin{array}{l}\text { Menggunakan hand } \\
\text { sanitizer }\end{array}$ \\
3. & $\begin{array}{l}\text { Mencuci tangan dengan } \\
\text { sabun }\end{array}$ & 96,2 \\
4. & Menghindari jabat tangan & 90,0 \\
5. & Menghindari kerumunan \\
6. & Menjaga jarak minimal 1 m & 91,5 \\
\hline
\end{tabular}

Kesadaran Masyarakat Jawa Timur Dalam Menerapkan Social Distancing Disertai Protokol Kesehatan Sebagai Tindakan Pencegahan dan Pengendalian Penyakit Covid-19

Menurut data Badan Pusat Statistik (BPS), telah dilakukan Survei Perilaku Masyarakat di Masa Pandemi COVID-19 menggunakan rancangan Non-Probability Sampling yang merupakan kombinasi dari Convenience, Voluntary dan Snowball Sampling untuk mendapatkan respon partisipasi sebanyak-banyaknya. Survei dilakukan kepada masyarakat Provinsi Jawa Timur dan dilaksanakan dalam kurun waktu 1 minggu yaitu tanggal 7-14 September 2020. Hasil survei yang dimaksud disajikan pada Tabel 3.

Tabel 3. Gambaran Kesadaran Masyarakat Jawa Timur Dalam Menerapkan Social Distancing Disertai Protokol Kesehatan Sebagai Tindakan Pencegahan dan Pengendalian Penyakit Covid-19

\begin{tabular}{lccc}
\hline \multicolumn{1}{c}{$\begin{array}{c}\text { Perilaku Kesadaran/Kepatuhan } \\
\text { Masyarakat Dalam Melakukan Tindakan } \\
\text { Pencegahan \& Pengendalian Covid-19 }\end{array}$} & $\begin{array}{c}\text { Tidak Pernah/ } \\
\text { Jarang Sekali }\end{array}$ & $\begin{array}{c}\text { Jarang/Kadang- } \\
\text { kadang/ Tidak } \\
\text { sering }\end{array}$ & $\begin{array}{c}\text { Sering/ Selalu } \\
\text { dilakukan }\end{array}$ \\
\hline Memakai masker & $2,02 \%$ & $6,00 \%$ & $91,98 \%$ \\
Menggunakan hand sanitizer & $5,32 \%$ & $16,97 \%$ & $77,71 \%$ \\
Mencuci tangan selama 20 detik dengan sabun & $5,37 \%$ & $19,25 \%$ & $75,38 \%$ \\
Menghindari jabat tangan & $4,10 \%$ & $14,06 \%$ & $81,85 \%$ \\
Menghindari kerumunan & $4,56 \%$ & $18,76 \%$ & $76,69 \%$ \\
Menjaga jarak minimal 1 meter & $5,48 \%$ & $20,98 \%$ & $73,54 \%$ \\
\hline
\end{tabular}

Kebijakan Dinas Kesehatan Provinsi Jawa Timur Yang Mendukung Optimalisasi Pencegahan dan Pengendalian Penyakit Covid-19

Kebijakan sudah sesuai peraturan pemerintah, dan untuk buku pedoman pencegahan dan pengendalian Covid-19 menggunakan pedoman dari Kemenkes. Terkait kebijakan dan buku pedoman tersebut telah disosialisasikan ke masyarakat dalam bentuk 3 materi yaitu anjuran untuk melakukan test swab antigen, pentingnya melakukan protokol kesehatan secara ideal, edukasi tentang 5M (Mencuci tangan, Memakai masker,
Menjaga jarak, Menjauhi kerumunan, mengurangi mobilitas) yang dishare ke media-media sosial seperti whatsapp, instagram, facebook dan media sosial lainnya. Namun perlu juga ditambahkan materi sosialisasi yang menyampaikan bahwa dasar dari 3 materi tersebut adalah beberapa kebijakan Kemenkes, Permenkes. Selain itu, perlu ditambahkan materi sosialisasi terkait urgensi dan pentingnya pelaksanaan PPKM yang didasari dari kebijakan-kebijakan Pemerintah salah satunya yaitu Instruksi Menteri Dalam Negeri (InMendagri) Nomor 35 tahun 2021. 
Kecukupan SDM Yang Bertugas Dalam Pencegahan dan Pengendalian Penyakit Covid-19 dan Kecukupan Anggaran/Dana Yang Dimiliki Dinas Kesehatan Provinsi Untuk Mendukung Terwujudnya Optimalisasi Pencegahan dan Pengendalian Penyakit Covid-19

Jumlah SDM di setiap RS menurut TT (tempat tidur) dapat dikatakan sudah mencukupi, namun ketika jumlah kasus melonjak, mengalami kekurangan tenaga kesehatan. Dan untuk RS lapangan yang diperuntukkan isolasi Covid-19 gejala ringan masih banyak kekurangan nakes. Selain itu, untuk jumlah petugas TLI (test lacak isolasi) secara ideal belum mencukupi, dikarenakan idealnya menurut kebijakan Kemenkes RI No. 4641 tahun 2021 menganjurkan bahwa petugas TLI (test lacak isolasi) di setiap Puskesmas harus mempunyai minimal 2 orang petugas TLI (test lacak isolasi). Untuk anggaran sudah cukup, namun belum menggandeng dan memanfaatkan anggaran-anggaran dari CSR perusahaan-perusahaan besar di wilayah Jawa Timur.

Fasilitas Kesehatan yang Dimiliki Di Wilayah Kerja Dinas Kesehatan Provinsi Jawa Timur

Fasilitas kesehatan di wilayah kerja Dinas Kesehatan Provinsi Jatim yang terdiri dari fasilitas kesehatan primer dan fasilitas kesehatan rujukan dari segi jumlah dapat dikatakan sudah cukup untuk memberikan pelayanan kesehatan khususnya dalam penanggulangan Covid-19, namun untuk RS rujukan Covid-19 masih banyak yang kekurangan tempat tidur maupun fasilitas penunjang lainnya.

Tingkat Pengetahuan Masyarakat Jawa Timur Tentang Cara Pencegahan dan Pengendalian Penyakit Covid-19

Tingkat pengetahuan atau persepsi masyarakat tentang keefektifan protokol kesehatan sudah cukup baik, namun untuk pelaksanaan protokol kesehatan di lapangan masih belum sebaik persepsinya. Sehingga perlu terus dilakukan edukasi tentang pentingnya pelaksanaan protokol kesehatan untuk mencegah Covid-19 di masyarakat sehingga pelaksanaan protokol kesehatan di lapangan dapat sebaik persepsi/pengetahuan masyarakat yang menyatakan efektif mengenai protokol kesehatan terhadap pencegahan Covid-19 masyarakat.

Kesadaran Masyarakat Jawa Timur Dalam Menerapkan Social Distancing Disertai Protokol Kesehatan Sebagai Tindakan Pencegahan Dan Pengendalian Penyakit Covid- 19

Perilaku kesadaran atau kepatuhan masyarakat dalam melakukan tindakan pencegahan \& pengendalian Covid-19 sudah cukup baik namun beberapa perilaku seperti menggunakan hand sanitizer, mencuci tangan selama 20 detik dengan sabun, menghindari jabat tangan, menghindari kerumunan, menjaga jarak minimal 1 meter angkanya masih dibawah 90\%, jadi sebaiknya masih perlu ditingkatkan lagi. Dengan demikian masyarakat dapat merasakan manfaatnya yaitu persebaran Covid-19 mulai berkurang dan individu yang terinfeksi ada harapan untuk sembuh.

Usulan Rekomendasi dalam Upaya Optimalisasi Pencegahan Dan Pengendalian Penyakit Covid-19 Di Masyarakat Terkait Rencana Atau Langkah-Langkah Ke Depan Dalam Upaya Optimalisasi Pencegahan Dan Pengendalian Penyakit Covid-19 Di Masyarakat

Pihak Dinas Kesehatan Provinsi Jawa Timur telah menyiapkan rencana operasional pencegahan dan pengendalian Covid-19 yang dinamakan rencana operasional strategi komunikasi pesan kunci Covid-19 di tingkat provinsi Jawa Timur yaitu Strategi komunikasi massa dengan melakukan kajian formatif, pemilihan dan pengembangan pesan kunci, pemilihan metode dan media, rancangan media serta monitoring dan evaluasi. Strategi Peran Serta Masyarakat dengan melakukan pendataan kesehatan warga, identifikasi kemungkinan faktor penyebab penularan dan potensi sumber daya, musyawarah masyarakat, menyusun rencana kegiatan, melaksanakan kegiatan serta pemantauan 
dan evaluasi. Strategi Kapasitas kader/ posyandu/ puskesmas dengan melakukan orientasi kader dan petugas, menyusun pedoman dan SOP serta optimalisasi penggunaan teknologi komunikasi. Keterlibatan pemangku kepentingan dengan melakukan mendorong terbitnya kebijakan percepatan pengurangan risiko penyebaran Covid-19, mendorong terbitnya kebijakan adaptasi kebiasaan baru, mendorong terbitnya kebijakan penegakan disiplin adaptasi kebiasaan baru.

Untuk persiapan yang sudah dilakukan dalam mengakomodir rencana atau langkahlangkah ke depan untuk mewujudkan optimalisasi pencegahan dan Pengendalian Penyakit Covid-19 Di Masyarakat pihak Dinas Kesehatan Provinsi Jawa Timur yaitu rapat koordinasi tingkat Provinsi dalam rangka optimalisasi PPKM Mikro, rapat webinar koordinasi PPKM Mikro dengan Kabupaten Kota, pembinaan dan pendampingan pencegahan covid-19 bersama TNI-POLRI di 17 Kabupaten/Kota, media promosi kesehatan dalam rangka pencegahan Covid-19 (ILM, ILM (Spot), Adlip).

Rencana Operasional Strategi Komunikasi Pesan Kunci Covid-19 Di Tingkat Provinsi Jawa Timur sudah baik, perlu dilakukan secara berkelanjutan, persiapan dalam mengakomodir rencana atau langkah-langkah ke depan dalam upaya optimalisasi pencegahan dan Pengendalian Penyakit Covid-19 Di Masyarakat dari Renop diatas dituangkan ke dalam RAK perlu dilakukan evaluasi anggaran supaya betul-betul optimal dan tepat sasaran dan anggaran dapat terserap 100\%. Untuk Pembinaan dan Pendampingan Pencegahan Covid-19 Bersama TNI-POLRI di 17 Kabupaten/Kota dan Media Promosi Kesehatan dalam rangka Pencegahan Covid19 (ILM, ILM (Spot), Adlip) perlu terus dilakukan secara berkelanjutan sampai kasus Covid-19 menurun secara signifikan.

\section{KESIMPULAN DAN SARAN}

Kebijakan Dinas Kesehatan Provinsi Jawa Timur untuk optimalisasi pencegahan dan pengendalian penyakit Covid-19 merujuk pada kebijakan yang berlaku. Untuk sumber daya manusia di fasilitas kesehatan primer yang bertugas dalam pencegahan dan pengendalian penyakit Covid-19 dapat dikatakan sudah cukup, kecuali untuk petugas TLI (test lacak isolasi) masih mengalami kekurangan petugas, untuk petugas tracer sejawa timur yang masuk di pembiayaan BOK saat ini berjumlah 11623 orang tracer.

Untuk penanganan penyakit Covid-19, Dinas Kesehatan Provinsi Jawa Timur mendapat anggaran dari beberapa sumber yaitu DAK (Dana Alokasi Khusus) non fisik, DBHCT (Dana Bagi Hasil Cukai \& Tembakau), BTT (Belanja Tidak Terduga). Untuk fasilitas kesehatan primer di wilayah kerja Dinas Kesehatan Provinsi Jatim yang terdiri dari Puskesmas Rawat Jalan dan Rawat Inap, Ponkesdes, Klinik Pratama Rawat Jalan dan Rawat Inap, Klinik Utama Rawat jalan dan Rawat inap yaitu total berjumlah 5938 faskes.

Untuk Pengetahuan/persepsi responden masyarakat Jawa Timur tentang cara pencegahan dan pengendalian penyakit Covid-19, jumlah persepsi paling tinggi yang menyatakan efektif mengenai protokol kesehatan memakai masker yaitu sebesar 91,8\%.

Adapun saran untuk optimalisasi pencegahan dan pengendalian penyakit Covid-19 pada masyarakat di wilayah Dinas Kesehatan Provinsi Jawa Timur yaitu supaya masyarakat lebih memahami 3 materi yang telah disosialisasikan oleh pihak Dinas kesehatan Provinsi Jatim yaitu tentang anjuran untuk melakukan test swab antigen, pentingnya melakukan prokes secara ideal, edukasi tentang $5 \mathrm{M}$ (Mencuci tangan, Memakai masker, Menjaga jarak, Menjauhi kerumunan, mengurangi mobilitas) yang dishare ke media-media sosial seperti whatsapp, instagram, facebook dan media sosial lainnya. Maka, perlu juga menambahkan materi sosialisasi yang menyampaikan bahwa dasar dari 3 materi tersebut adalah beberapa kebijakan dari Kemenkes dan Permenkes. Selain itu, perlu ditambahkan materi sosialisasi terkait urgensi dan pentingnya pelaksanaan PPKM 
yang didasari dari kebijakan-kebijakan Pemerintah salah satunya yaitu Instruksi Menteri Dalam Negeri (InMendagri) Nomor 35 tahun 2021. Mengadakan pengumuman kebutuhan tenaga kesehatan dan melakukan perekrutan tenaga kesehatan untuk antisipasi lonjakan kasus Covid-19 dan penambahan tenaga kesehatan yang ditempatkan di RS lapangan. Selain itu, mengadakan suatu program yang bertujuan memberikan perhatian lebih terkait monitoring dan pemeliharaan kondisi fisik dan kondisi kesehatan para tenaga kesehatan. Adakan MOU dengan perusahaan-perusahaan besar di wilayah Jawa Timur dalam rangka untuk menggandeng dan memanfaatkan anggarananggaran program CSR penanggulangan dan pencegahan Covid-19 dari perusahaanperusahaan besar di wilayah jawa timur. Adakan edukasi secara rutin tentang pentingnya pelaksanaan protokol kesehatan untuk mencegah Covid-19 di masyarakat sehingga pelaksanaan protokol kesehatan pada masyarakat jawa timur dapat lebih baik lagi.

\section{REFERENSI}

Addin Mendeley Bibliography CSL_BIBLIOGRAPHY Purwanto, A. (2020) 'Studi Explorative Dampak Pandemic Covid19 Terhadap Proses Pembelajaran Online Di Sekolah Dasar', Jurnal of Education, Psychology And Counseling, II(1), pp. $1-2$.

Dinas Kesehatan Provinsi Jawa Timur. (2020). Aksi Promkes Di Masa Pandemi. Seksi Promosi Kesehatan dan Pemberdayaan Masyarakat Tahun 2020.

Backer, J., Klinkenberg, D. \& Wallinga, J., (2020). Incubation period of 2019 novel coronavirus (2019-nCoV) infections among travellers from Wuhan, China. pp. 20-28

https://www.eurosurveillance.org/conte $\mathrm{nt} / 10.2807 / 1560$ -

7917.ES.2020.25.5.200 0062.

Centers for Disease Control and Prevention (CDC)., (2020). Symptom and Diagnosis. s.l., $\quad$ s.l.: $\quad$ s.n. https://www.cdc.gov/

coronavirus/about/symptoms.html.

Centers for Disease Controland Prevention (CDC), (2020). Coronavirus. s.l.,, s.1.: s.n.

https://www.cdc.gov/coronavirus/index. html.

Islami, N. W., Yuwanto, L. and Sudibyo, E. (2021) 'Strategi Peningkatan Kesadaran Masyarakat Dalam Penerapan Tatatan Kebiasaaan Baru di Masa Pandemi Covid-19 di Kabupaten Malang', Karta Raharja, 2(1), pp. 34-44.

Keputusan Gubernur Jawa Timur Nomor 188/31/KPTS/013/2021. Perubahan Ketujuh Atas Keputusan Gubernur Jawa Timur Nomor 188/125/KPTS/013.2020 Tentang Penetapan Rumah Sakit Rujukan Penyakit Corona Virus Disease 2019 Di Jawa Timur

Keputusan Menteri Kesehatan Republik Indonesia. (2021). Panduan Pelaksanaan Pemeriksaan, Pelacakan Karantina dan Isolasi Dalam Rangka Percepatan Pencegahan dan Pengendalian Corona Virus Disease 2019 (COVID-19)., Jakarta: Kemenkes RI Nomor HK.01.07/MENKES/4641/2021.

Kementerian Kesehatan Republik Indonesia. (2017). Pedoman Kesiapsiagaan Menghadapi MERSCoV di Indonesia. Jakarta, Kemenkes RI.

Kementerian Kesehatan Republik Indonesia. (2020). Pedoman Pencegahan dan Pengendalian Corona Virus Disease 2019 (COVID-19).

Keputusan Menteri Kesehatan Republik Indonesia. (2020). Pedoman Pencegahan dan Pengendalian Corona Virus Disease 2019 (COVID-19). Jakarta: Kemenkes RI Nomor HK.01.07/MENKES/413/2020.

Shereen, M. et al. (2020). Covid-19 Infection: Origin, Transmission and Characteristics of Human Coronaviruses., $\quad$ s.1., https://doi.org/10.1016/j.jare.2020.03.0 05 
Sugiyono. (2011). Metode Penelitian Kuantitatif dan $R \& D$. Bandung: Alpabeta. WHO, 2020. Coronavirus. s.l., $\quad$ https://www.who.int/healthtopics/coronavirus.

Situasi Terkini Perkembangan Coronavirus Disease.

(2021). https://infeksiemerging. kemkes.go.id/ situasi-infeksi-emerging/situasi-terkiniperkembangan coronavirus-diseasecovid-19-07-februari-2021

World Health Organization (WHO). (2020) .https://www.who.int/healthtopics/coronavirus. 